\title{
Use of an immersible scintillation counter in the urinary vitamin $B_{12}$ excretion test
}

J. GOUGH, w. GOUGH, and S. ROATH From the
Department of Clinical Haematology, University
and. Royal Infirmary, Manchester, and the
Department of Physics, University College of
South Wales, Cardiff

The urinary excretion test for vitamin $\mathbf{B}_{12}$ absorption devised by Schilling, Clatanoff, and Korst (1955) and Callender and Evans, in the same year, is probably the most commonly used method in the assessment of this function of the gut, and particularly in the diagnosis of pernicious anaemia. The reproducibility of the results obtained in this manner and the convenience of the procedure compared with the others employed, e.g., surface counting over the liver (Glass, Boyd, Gellin, and Stephanson, 1954), stool counting (Heinle, Welch, Scharf, Meacham, and Prusoff, 1952), or estimating blood radioactivity after a given dose of radioactive cobalt-labelled $B_{12}$ (Booth and Mollin, 1956), make the urinary excretion method the choice of many laboratories.

The urine samples obtained containing labelled $B_{12}$ may be counted in a 'ring' type Geiger-Mueller counter, or by activated crystal scintillation counters in well, annular, or end-on settings. In this study the EKCO type N691 general purpose scintillation detector, fitted with an N609, crystal was used; it is of a completely immersible design and appeared to be potentially suitable for the counting of large samples of radioactive liquids. Using the technique described, the value of this counter in the Schilling test was assessed, after an initial evaluation of the accuracy of the method. The apparatus was tested in view of its capability of producing adequately high counts in a short time.

\section{METHOD}

A standard solution of cobalt ${ }^{58}$-labelled vitamin $\mathbf{B}_{12}$ was prepared by dissolving the contents of an ampoule containing $1.0 \mu \mathrm{c}$. of this material (Radiobiological Laboratory, Amersham) in 1,000 ml. water. Dilutions of this standard solution were prepared and $10 \mathrm{ml}$. aliquots of each dilution counted in an annular type counter (EKCO N550A with an N533A crystal) and N530 scaler, as described by Berlyne, Liversedge, and Emery (1957), for 3,000 seconds and 100 seconds respectively for each dilution. At the same time $500 \mathrm{ml}$. samples of the same dilutions were prepared and counted using the type N691 detector in conjunction with a type N640 amplifier and N530 scaler for 100 seconds. The solutions were contained in $600 \mathrm{ml}$. Pyrex beakers shielded by $1 \frac{1}{2}$ in. of lead brick on a cast iron base, and the detector

Received for publication 18 March 1964. immersed in the fluid to the level at which the crystal is fitted. A simple vertical mounting for the cylindrical detector was arranged to facilitate its removal, washing (in running tap water), and re-immersion. Background counts were performed using $500 \mathrm{ml}$. tap water in the same type of beaker. The results of these studies are shown in Table I.

\section{TABLE I}

ESTIMATION OF PERCENTAGE ACTIVITY OF DILUTIONS OF STANDARD SOLUTION

\begin{tabular}{|c|c|c|}
\hline $\begin{array}{l}\text { Dilution }(\%) \text { of } \\
\text { Standard Solution }\end{array}$ & $\begin{array}{l}\text { Estimated Percentage } \\
\text { of Standard Solution }\end{array}$ & $\begin{array}{l}\text { Standard Error }(\%) \\
\text { of Standard Solution }\end{array}$ \\
\hline $\begin{array}{c}\text { Counting for } 3,000 \\
2 \cdot 5 \\
5 \cdot 0 \\
10 \cdot 0 \\
20 \cdot 0 \\
40 \cdot 0\end{array}$ & $\begin{array}{c}\text { onds using } 10 \mathrm{ml} \text {. sample } \\
2.43 \\
4 \cdot 89 \\
10 \cdot 15 \\
20 \cdot 04 \\
40 \cdot 23\end{array}$ & $\begin{array}{c}\text { e in annular counter } \\
0.13 \\
0.17 \\
0.17 \\
0.22 \\
0.30\end{array}$ \\
\hline $\begin{array}{c}\text { Counting for } 100 \\
2 \cdot 5 \\
5 \cdot 0 \\
10 \cdot 0 \\
20 \cdot 0 \\
40 \cdot 0\end{array}$ & $\begin{array}{c}\text { ds using } 500 \mathrm{ml} . \text { sample } \\
2 \cdot 23 \\
4 \cdot 67 \\
9 \cdot 80 \\
20 \cdot 17 \\
39 \cdot 10\end{array}$ & $\begin{array}{l}\text { with immersible counte } \\
0.09 \\
0.10 \\
0.13 \\
0.18 \\
0.25\end{array}$ \\
\hline $\begin{array}{c}\text { Counting for } 100 \\
2 \cdot 5 \\
5 \cdot 0 \\
10 \cdot 0 \\
20 \cdot 0 \\
40 \cdot 0\end{array}$ & $\begin{array}{c}\text { Is using } 10 \mathrm{ml} \text {. sample } \\
3 \cdot 14 \\
5 \cdot 04 \\
9 \cdot 39 \\
19 \cdot 1 \\
42 \cdot 0\end{array}$ & $\begin{array}{c}\text { in annular counter } \\
0.66 \\
0.81 \\
0.91 \\
1.15 \\
1.64\end{array}$ \\
\hline
\end{tabular}

In addition to the above, Schilling tests were carried out on 12 patients in whom pernicious anaemia, malabsorption syndromes, or other defects were suspected. Co ${ }^{58}$-labelled vitamin $B_{12}$ of $1.0 \mu \mathrm{c}$. activity, $1 \mu \mathrm{g}$., was given by mouth, followed by $1,000 \mu \mathrm{g}$. of the nonradioactive form by injection, and the urine collected for the following 24 hours. The 'usual' method for this laboratory of counting $10 \mathrm{ml}$. urine samples for 3,000

\section{TABLE II}

RESULTS OF URINARY $B_{12}$ EXCRETION TESTS

\begin{tabular}{|c|c|c|c|}
\hline $\begin{array}{l}\text { Case } \\
\text { No. }\end{array}$ & Indication for Test & $\begin{array}{l}\text { Percentage } \\
\text { Excretion in } \\
10 \mathrm{ml} \text {. } \\
\text { Sample for } \\
3,000 \\
\text { Seconds } \\
\text { (annular } \\
\text { counter) }\end{array}$ & $\begin{array}{l}\text { Percentage } \\
\text { Excretion in } \\
500 \mathrm{ml} \text {. } \\
\text { Sample for } \\
100 \text { Seconds } \\
\text { (immersible } \\
\text { counter) }\end{array}$ \\
\hline $\begin{array}{l}1 \\
2\end{array}$ & $\begin{array}{l}\text { ? Malabsorption syndrome } \\
\text { ? Subacute combined }\end{array}$ & $3 \cdot 5$ & $3 \cdot 1$ \\
\hline & degeneration & 16.9 & $16 \cdot 2$ \\
\hline 3 & Pernicious anaemia & $0 \cdot 7$ & $0 \cdot 7$ \\
\hline 4 & Undiagnosed anaemia & $32 \cdot 5$ & $28 \cdot 3$ \\
\hline 5 & Undiagnosed anaemia & $18 \cdot 8$ & $17 \cdot 4$ \\
\hline 6 & ? Malabsorption syndrome & $12 \cdot 2$ & $11 \cdot 8$ \\
\hline 7 & ? Pernicious anaemia & $3 \cdot 6$ & $3 \cdot 2$ \\
\hline 8 & $\begin{array}{l}\text { Hodgkin's disease, } \\
\text { megaloblastic marrow }\end{array}$ & $6 \cdot 1$ & $5 \cdot 8$ \\
\hline 9 & $\begin{array}{l}\text { (a) Pernicious anaemia } \\
\text { (b) Repeated with intrinsic }\end{array}$ & 0.7 & 0.8 \\
\hline & factor & $4 \cdot 7$ & $4 \cdot 6$ \\
\hline 10 & Post-gastrectomy anaemia & $0 \cdot 1$ & 0.4 \\
\hline 11 & Post-gastrectomy anaemia & 3.9 & $3 \cdot 5$ \\
\hline 12 & ? Pernicious anaemia & $7 \cdot 8$ & $7 \cdot 6$ \\
\hline
\end{tabular}


seconds in the annular counter, the time found necessary to obtain a significant number of counts, was used, as was the 100 -second count using the immersible detector. The presumptive diagnosis and a comparison of the results obtained in these subjects are shown in Table II.

The results in Table $I$ show that the immersible detector provided in 100 seconds figures whose standard errors compare favourably with those obtained by counting $10 \mathrm{ml}$. samples in the annular detector for 3,000 seconds. When $10 \mathrm{ml}$. samples were counted for only 100 seconds a high standard error was incurred. Standard errors were calculated using the formula given by Topping (1960). The ability of the immersible detector to count a large volume of fluid enables significantly high counts to be reached in a conveniently short time. The use of the largest practicable samples is generally advocated (Veall and Vetter, 1958; Quimby and Feitelberg, 1963) as the error in counting is reduced.

\section{CONCLUSIONS}

The N691 detector described can be utilized in the urinary $B_{12}$ excretion test to obtain accurate results in a short time as it is able to count large samples of radioactive fluids. It is suggested that it need not replace the current equipment used for this test. If it is acquired as a general purpose versatile gamma-ray counter, it is well suited for use in this manner. Any counter of this type used in this or similar experiments should be thoroughly checked to see that it is watertight initially; the original unit tested was defective in this respect.

We wish to thank Dr. M. C. G. Israëls for his help and Ekco Ltd. for the loan of apparatus.

\section{REFERENCES}

Berlyne. G. M., Liversedge, L. A., and Emery, E. W. (1957). Lancet, 1 294.

Booth, C. C., and Mollin, D. L. (1956). Brit. J. Haemat., 2, 223.

Callender, S. T., and Evans. J. R. (1955). Clin. Sci., 14, 295.

Glass, G. B. J., Boyd, L. J., Gellin, G. A., and Stephanson, L. (1954). Arch. Biochem., 51, 251.

Heinle, R. W., Welch, A. D., Scharf, V., Meacham, G. C., and Prusoff, W. H. (1952). Trans. Ass. Amer. Phycns., 65, 214.

Quimby, E. H., and Feitelberg, S. (1963). Radioactive Isotopes in Medicine and Biology, 2nd ed., vol. 1. Kimpton, London.

Schilling, R. F., Clatanoff, D. V., and Korst, D. R. (1955). J. Lab. clin. Med., 45, 926.

Topping, J. (1960). Errors of Observation and Their Treatment. Revised ed., p. 20 . Institute of Physics, London.

Veall, N., and Vetter, H. (1958). Radioisotope Techniques in Clinical Research and Diagnosis. Butterworth, London.

\section{A simple constant-infusion apparatus for very small quantities of fluid delivered over long periods}

\section{E. A. WRIGHT From the Department of Pathology, St. Mary's Hospital Medical School, London}

Constant-injection devices are mostly expensive and complex. An extremely simple, reliable, and inexpensive device particularly suited to delivering small volumes over long periods is described below.

Essentially it consists of a micrometer syringe driven by a small synchronous electric motor and coupled so that the driving spindle of the motor disengages when the required volume has been discharged (Fig. 1). A suitable micrometer syringe is the standard commerically available Agla syringe. The only modification required is the attachment of the coupling device, which consists of a slotted perspex tube fixed to the end of the micrometer head. This slot takes the driving rods of the motor spindle (Fig. 2). A wide range of synchronous motors is available ranging from one revolution per second to one revolution per week.

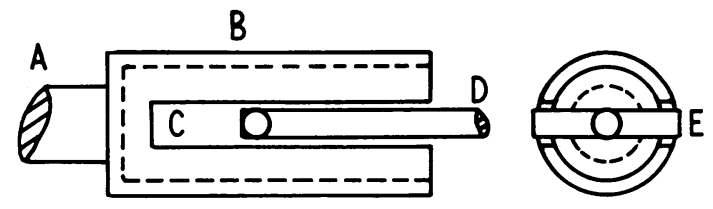

FIG. 2. Simplified diagram of side and end elevation of coupling. $(A)$ end of micrometer head; $(B)$ perspex tube; (C) slot; (D) spindle from motor; $(E)$ driving rod at end of spindle.

In the model illustrated (Fig. 1) the Agla syringe is held firmly in two perspex uprights by screws. The motor is held in place by long knurled screws. The depth of the driving rods of the spindle in the perspex tube will then correspond to the maximum movement of the micrometer head (and therefore the movement of the syringe plunger) which can occur before the rods disengage.

Received for publication 23 April 1964.

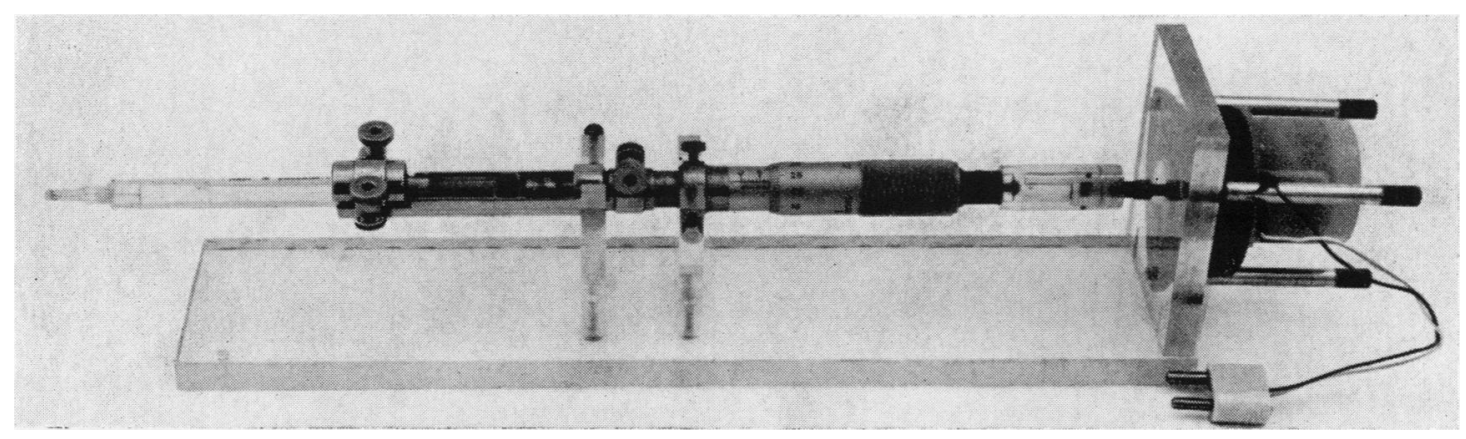

FIG. 1. Photograph of the assembled constant infusion apparatus. 